\title{
Acute-onset diplopia in a case of nephrotic syndrome
}

\author{
Nripen Gaur, ${ }^{1}$ Pradeep Sharma, ${ }^{1}$ Brijesh Takkar, ${ }_{1}^{1}$ Jagjeet Singh ${ }^{2}$
}

'Department of Ophthalmology, Dr. Rajendra Prasad Centre for Ophthalmic Sciences, All India Institute of Medical Sciences, New Delhi, India ${ }^{2}$ Department of Radiology, All India Institute of Medical Sciences, New Delhi, India

\section{Correspondence to}

Professor Pradeep Sharma, drpsharma57@yahoo.com

Accepted 27 July 2017

\section{DESCRIPTION}

A 12-year-old boy was evaluated in our emergency services for complaints of diplopia and mild generalised headache since past 4 days. The patient was a known case of frequently relapsing idiopathic nephrotic syndrome and was currently in remission since 5 days. He was normal and oriented on general physical and systemic examination. Urine microscopy had revealed only traces of protein on repeated evaluation, and serum albumin was $2.2 \mathrm{~g} / \mathrm{dL}$ on presentation. Visual acuity was $6 / 6$ in both eyes, and the pupillary reflexes were brisk. The ocular motility examination revealed an esotropia of 20 prism dioptres (figure 1A) along with limitation of the abduction movements in both eyes (figure 1B,C). However, right eye showed a greater limitation compared with left eye. Anterior segment of both the eyes were normal, but the fundus examination revealed bilateral severe established optic disc oedema (figure 2A,B). The patient was diagnosed to have papilloedema with bilateral abducens palsy as a false localising sign. An urgent contrast-enhanced computerised tomography (CECT) scan was ordered for determining the cause of raised intracranial tension (ICT). The CECT scan of the head revealed an empty delta sign wherein the contrast outlines the triangular filling defect suggestive of thrombosis of the superior sagittal sinus (figure $2 \mathrm{C}$ ). A paediatric review was advised where the patient was started on anticoagulant therapy (enoxaparin and heparin). There was rapid resolution of symptoms with the treatment. Magnetic resonance venography (MRV) was done 3 days later, which revealed non-opacification of the posterior part of the superior sagittal sinus
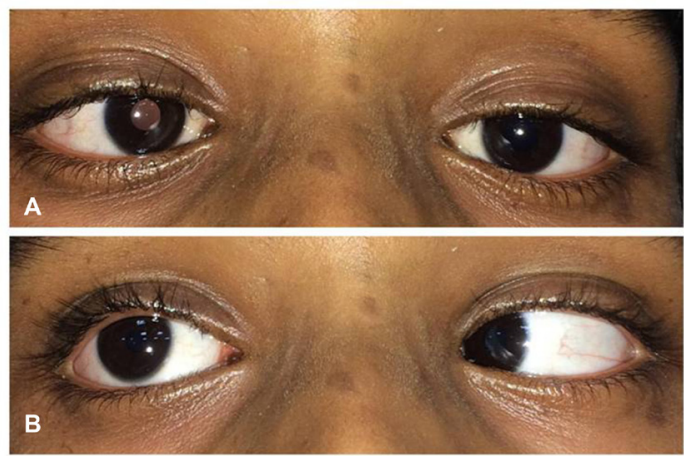

CrossMark

To cite: Gaur N, Sharma P, Takkar B, et al. BMJ Case Rep Published Online First: [please include Day Month Year]. doi:10.1136/bcr-2017221475

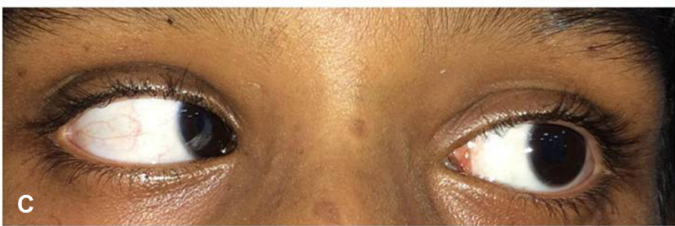

Figure 1 (A) Esotropia in primary position and (B and C) abduction deficit in both eyes.
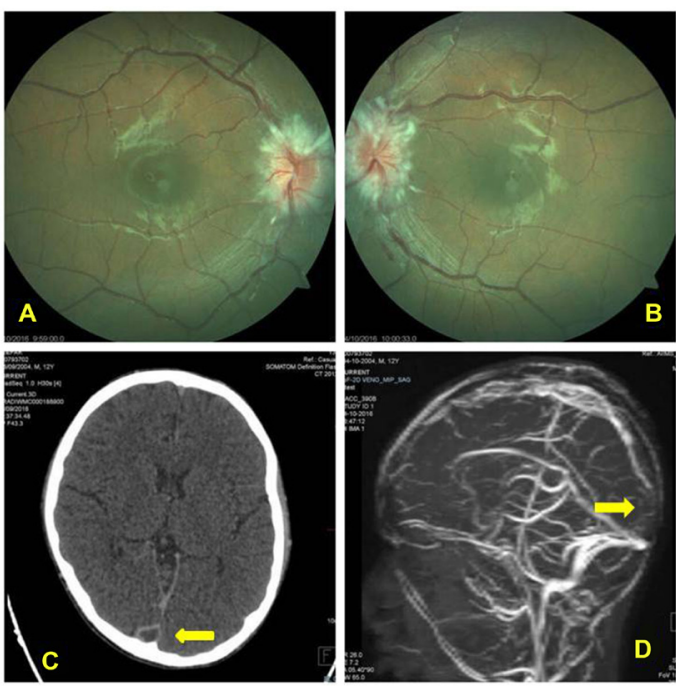

Figure 2 (A, B) Papilloedema, (C) empty delta sign suggestive of sagittal sinus thromboses (arrow), (D) MRV revealing non-opacification of the posterior part superior sagittal sinus (arrow). MRV, magnetic resonance venography.

(figure 2D). At 1 month of follow-up, the patient reported complete resolution of the symptoms and attained binocular single vision in all gazes.

Sixth nerve palsy may sometimes be a false localising sign in context of raised ICT. Stretching of the nerve along its long course or compression against petrous ligament or ridge has been suggested to be the mechanism for this phenomenon in the presence of raised ICT. A bilateral sixth nerve palsy in children in the presence of papilloedema usually points towards the presence of intracranial pathology like an intracranial space occupying lesion. Thromboembolism is a serious complication of the nephrotic syndrome, which occurs due to its association with a hypercoagulable state. ${ }^{1}$ The intensity of hypercoagulability is related to the degree of hypoalbuminaemia and explains why this child had a thrombotic event following very recent remission. ${ }^{2}$ Until now, there is only one previous report of bilateral sixth nerve palsy as the presenting complaint of superior sagittal sinus thrombosis occurring in

Learning points

- Sinovenous thrombosis is a rare but serious complication of nephrotic syndrome.

- The presence of a recent-onset strabismus in a patient with nephrotic syndrome should alert the physician of an underlying serious pathology. 
the context of childhood nephrotic syndrome. ${ }^{3}$ In that case, however, the patient had presented with generalised oedema that was not seen in our patient.

Contributors BT and NG contributed to diagnosis, workup, writing the manuscript and performing critical revision. JS contributed to diagnosis and management. PS holds the overall responsibility to the presentation and contributed in diagnosis and performing critical revision of the manuscript.

Competing interests None declared.

Patient consent Guardian consent obtained.

Provenance and peer review Not commissioned; externally peer reviewed.
(C) BMJ Publishing Group Ltd (unless otherwise stated in the text of the article) 2017. All rights reserved. No commercial use is permitted unless otherwise expressly granted.

\section{REFERENCES}

1 Kang SK, Park SK. Nephrotic Syndrome Associated with Renal Vein Thrombosis. Korean J Intern Med 1987;2:125-30.

2 Kanfer A. Coagulation factors in nephrotic syndrome. Am J Nephrol 1990;10 (Suppl 1):63-8.

3 Zaragoza-Casares P, Gómez-Fernández T, Zato-Gómez de Liaño MA, et al. Superior sagittal sinus thrombosis and bilateral sixth-nerve palsy in a child with nephrotic syndrome. Pediatr Nephrol 2007;22:753-5.

Copyright 2017 BMJ Publishing Group. All rights reserved. For permission to reuse any of this content visit

http://group.bmj.com/group/rights-licensing/permissions.

BMJ Case Report Fellows may re-use this article for personal use and teaching without any further permission.

Become a Fellow of BMJ Case Reports today and you can:

- Submit as many cases as you like

Enjoy fast sympathetic peer review and rapid publication of accepted articles

- Access all the published articles

Re-use any of the published material for personal use and teaching without further permission

For information on Institutional Fellowships contact consortiasales@bmjgroup.com

Visit casereports.bmj.com for more articles like this and to become a Fellow 